\title{
Democracy and Multilateralism: The Case of Vote Buying in the UN General Assembly
}

\author{
David B. Carter and Randall W. Stone
}

\begin{abstract}
Democracies are more supportive of US positions on important votes in the UN General Assembly than of nondemocracies. Is this because democracies share common perspectives, or does this pattern reflect coercion? Since 1985, US law has stipulated that the US State Department identify important votes and that aid disbursements reflect voting decisions. To unravel these alternative explanations, we introduce a strategic statistical model that allows us to estimate voting preferences, vulnerability to influence, and credibility of linkage, which are theoretical quantities of interest that are not directly observable. The results reject the hypothesis of shared democratic values: poor democracies have voting preferences that are more oppositional to US positions than autocracies, and they are more willing than autocracies to take symbolic stands that may cost them foreign aid. Democracies support US positions, however, because US aid linkages are more credible when directed toward democratic countries. Splitting the sample into Cold War and post-Cold War segments, we find that the end of the Cold War changed the way US linkage strategies treated allies and leftand right-leaning governments, but the effects of democracy remained constant.
\end{abstract}

The relationship between multilateralism and democracy has risen in prominence in the post-Cold War period as international organizations have become increasingly influential and their members have become increasingly democratic. Delegation to international authorities involves some sacrifice of national sovereignty, and observers frequently lament the resulting democratic deficits. Democratic procedures ameliorate these concerns, and almost all multilateral organizations have provisions for voting, but these formal rules are often overridden by informal procedures that reflect the influence of powerful countries. ${ }^{1}$ On the other hand, multilateralism is conceived as a means of restraining the exercise of hegemonic power ${ }^{2}$ and is widely believed to strengthen democracy. Membership in international organizations has been credited with preventing new democracies from sliding back into authoritarianism, and with improving the quality of democratic governance. ${ }^{3}$ A first step toward

We would like to thank Joanne Gowa, Matthew Winters, three anonymous reviewers, the $I O$ editors, as well as seminar participants at Cornell University, the University of Pennsylvania, the University of Warwick, the London School of Economics, the University of Illinois at Champaign-Urbana, and participants at several conferences for comments that improved this article. Any mistakes remain our responsibility.

1. Stone 2011.

2. Lake 2002.

3. See Pevehouse 2002; Pevehouse and Mansfield 2006; and Keohane, Macedo, and Moravscik 2009. 
unraveling these questions is to investigate how democracies interact with each other as they seek to govern multilateral organizations. As the leading state in the international system, does the United States cooperate with other democracies, or does it attempt to coerce them?

We use vote buying in the United Nations General Assembly (UNGA) as a case study. The UNGA is among the most democratic of international institutions, and the low stakes involved in its nonbinding resolutions have made it a relatively polite diplomatic forum. Nevertheless, US foreign policy seeks to influence the vote tallies on important UN votes, so the way in which the United States interacts with other democracies in this setting may be revealing. Since the mid-1980s, US law has required the US State Department to report how countries vote in the UN on issues that are regarded as important to US interests, and has required the United States Agency for International Development (USAID) to use countries' voting records on these issues as a criterion for disbursing aid. Buying votes is official policy. How we interpret this, however, may depend on whose votes are being bought, and for what reasons. We start with the observation that democracies tend to support the United States on votes designated by the State Department as important to US interests more frequently than autocracies. A prima facie case exists, therefore, for the interpretation that democracies support the United States because they share common norms and a community of interests. If this is the case, the experience of cooperating on issues of common concern at the multinational level should reinforce those norms. There should be no tension between participation in multilateral cooperation and faithfully representing the preferences of national constituents, and multilateral governance should become increasingly legitimate as more of the participating governments become democratic.

Because the United States is in the market for votes, however, strategic interaction creates inference problems. Strategic votes reflect both government preferences and the threats or promises that are used to influence votes, so rather than indicating similar preferences, the voting behavior of democracies might reflect US strategies. If the United States systematically rewards or punishes voting behavior by democracies differently than voting by autocracies, and aid recipients are sensitive to the incentives this creates, the difference between democratic and autocratic voting in the UN may simply represent the effect of coercion. In unraveling what this voting behavior means, it is essential to explicitly account for the strategic incentives facing voters and vote buyers.

We introduce a statistical technique that helps us untangle voting preferences, susceptibility to influence by the United States, and the credibility of US influence attempts. We tap into strategic voting with a relatively simple structural model by taking advantage of the fact that all important resolutions comfortably pass. Thus, US policy is not buying votes to ensure or block passage of resolutions; rather, the United States is buying votes to appear less isolated and to purchase legitimacy on key foreign policy issues. Accordingly, we estimate a strategic statistical model in which countries decide how to vote on an issue that has been designated by the State Department as important to US interests, and then the United States decides 
whether to withhold a portion of committed aid, if the country has voted against the US position, or reward the aid recipient with additional aid, if the country has voted in favor of the US position. Because this model captures the strategic element of voting, we are able to evaluate the effect of anticipated punishments or rewards on voting decisions. Furthermore, we are able to differentiate which regimes are most susceptible to influence and which influence attempts are most credible.

Our findings are disappointing for advocates of multilateral governance. We find that democratic countries are in fact more strongly opposed to US policy preferences than nondemocratic countries, so norms or a community of interests do not explain their voting behavior. Left to their own devices, democratic countries would oppose US positions at higher rates than authoritarian countries. Democracies are presumably more likely to oppose the United States because they are more sensitive to the preferences of the median voter, which generally are not favorable to US foreign policy (for example, support of Israel, the embargo of Cuba, or wars in the Middle East). This casts US efforts to cajole UN members to support its preferred positions in an unfavorable light. Instead, we find that democracies are more likely to comply with US influence attempts because they are the countries that are most frequently targeted. It is costly for the United States to punish its authoritarian allies, which often depend on aid for political survival, and generally receive aid because they are strategically important rather than because they are deserving. Conversely, it can be politically embarrassing at home to reward authoritarian countries for their votes. Consequently, US policy tends to target democracies when it tries to round up support. Our results indicate that the fact that US threats and rewards are more credible when they are directed at democracies accounts for the high rate of compliance with US preferences by democracies.

Additional results show that the United States punishes and rewards recipients for their votes differently depending on the left-right political orientations of their governments, their levels of development, and their alliance relationships, and that these variations in credibility are key to explaining the effectiveness of US influence attempts. To further investigate these relationships, as well as to probe the robustness of our findings about democracy, we split our data into Cold War and post-Cold War samples. We find that the end of the Cold War was a watershed in US vote-buying strategy in the UN, although vote buying occurred in both samples. Our findings suggest that factors relevant to US competition with the Soviet Union play an important role in explaining the US propensity to punish aid recipients during the Cold War, but these factors lose explanatory power in the post-Cold War era. In particular, the United States was much more willing to punish left-leaning governments and reward right-leaning governments during the Cold War, but this pattern disappeared when the Cold War came to an end. Similarly, the United States was reluctant to punish its allies during the Cold War, but became more likely to punish allies than non-allies after the Cold War. The end of the Cold War did not affect the determinants of recipient countries' behavior. Furthermore, our central findings about the effects of democracy are consistent during and after the Cold War. This indicates that the strategy of coercing democracies is an enduring feature of US foreign policy, rather than a 
consequence of the special circumstances that prevailed during the Cold War. Finally, we provide a direct test of whether our strategic choice model outperforms a nonstrategic model using the same covariates, which can be interpreted substantively as a test of whether recipient voting behavior is significantly influenced by US aid disbursements. The result rejects the hypothesis that US aid policy does not influence UN voting.

\section{Democracy and UN Voting}

Democracies support US positions on issues of importance to US foreign policy in the UNGA 41 percent of the time, while nondemocracies support the US position only 29 percent of the time. ${ }^{4}$ Does this reflect a coincidence of preferences among democratic countries? Alternatively, are democracies more likely to support US positions because they are more likely to be coerced or rewarded? We argue that democratic governments hold policy positions that are more inherently opposed to US policy than autocracies do, but that they support US positions nevertheless because they are targeted more systematically by US policy-makers for influence attempts. The most optimistic interpretation of UN voting patterns holds that democracies vote together because they hold similar world views and pursue complementary goals in foreign policy. This is consistent with the observations that democracies are unlikely to engage in militarized interstate disputes against each other, ${ }^{5}$ and that when disputes do arise between democracies, it is almost always possible to settle them without escalation. ${ }^{6}$ The pattern of peaceful conflict resolution among democracies is widely attributed to common values. ${ }^{7}$ Furthermore, democracies are more likely to form alliances to support each other than to ally with nondemocracies. ${ }^{8}$

Patterns of democratic affinity are not limited to security affairs. Democracies trade with each other more intensively than with nondemocracies, controlling for factors such as the size of their economies and the distance between them, and they are more inclined to grant each other commercial concessions. ${ }^{9}$ Democracies sign more treaties with other democracies than with nondemocracies, and they share more memberships in international organizations. Common membership in international organizations has been credited with resolving disputes and facilitating cooperation. ${ }^{10}$

Contradicting this rosy view is the deep division in public opinion between developed and developing countries. US foreign policy, and to a lesser degree, American institutions and values, are generally unpopular in the developing world, particularly

4. A difference in means test and a Chi-square test of independence strongly confirm the statistical significance of this difference. We classify states with a Polity score of at least 6 as democracies.

5. Bennett and Stam 2000.

6. See Dixon 1994; and Huth and Allee 2002.

7. See Russett 1993; and Russett and Oneal 2001.

8. Lai and Reiter 2000.

9. See Mansfield, Milner, and Rosendorff 2000; and Gartzke 2007.

10. Mitchell and Hensel 2007. 
in the Middle East and South Asia. Furthermore, there is no consistent evidence that the publics of democratic countries tend to hold more positive views of the United States than do those of authoritarian countries. ${ }^{11}$ A strong bloc of votes consistently supported the United States during the early decades of the UN history, but by the mid-1970s the United States frequently found itself isolated, and was on the losing side of most votes by the 1980s. Cold War themes continued to command the allegiance of a wide range of US democratic allies, but even the staunchest US allies became increasingly critical of US positions on Central America, the Middle East, South Africa, and how best to promote human rights in the Soviet bloc. Some of these disagreements were tactical and resolved themselves with the end of the Cold War, but new disagreements arose over how to deal with nuclear proliferation, terrorism, and the dilemmas posed by Iraq, Iran, and North Korea. Meanwhile, democracies in the developing world chafed under the Washington Consensus and became restive under a global trade regime that appeared slanted in favor of the interests of advanced economies. The legitimacy of the international institutions where the United States exercised decisive influence came under question, and this was reflected in voting in the international forum that the United States found hardest to control, the UNGA.

Furthermore, there is reason to believe that the leaders of democracies derive more benefits than autocrats from taking symbolic stands that are critical of the United States. Democratic leaders face reselection through elections, so their tenure in office is intimately related to their popularity; this connection is more tenuous for autocrats. If the United States takes a position that is unpopular with the target country's electorate, it may be politically costly for a democratic leader to vote in support. Furthermore, leaders who face domestic criticism for being too closely aligned with the United States - for example, because they have accepted International Monetary Fund (IMF) tutelage of their economic policies, or have supported US-led military operations - may find symbolic votes in the UNGA a welcome opportunity to deflect criticism by demonstratively following public opinion. Autocrats generally rely on the support of a narrow coalition of elites to retain their positions, so they are largely insulated from the pressure to conform to public opinion. ${ }^{12}$

Rather than reflecting inherent preferences, it is possible that democratic countries vote more consistently with the United States because they are susceptible to US influence. Several studies have found associations between UN voting and US foreign aid. ${ }^{13}$ It is plausible that foreign aid is explicitly used to influence UN voting - at least

11. See Chiozza 2007 and 2009.

12. Bueno de Mesquita and Smith 2007.

13. See Wittkopf 1973; Rai 1980; Wang 1999; and Dreher, Nunnenkamp, and Thiele 2008. In contrast, Kegley and Hook (1991) find little evidence that the explicit linkage between UNGA voting on important issues and aid disbursements established in the 1980s has any effect on voting behavior. Most early work did not distinguish between important votes and ordinary votes, although Wittkopf defined "important" votes as those in which the United States and Soviet Union disagreed, and Wang 1999 focuses on votes identified as important by the US State Department. Dreher, Nunnenkamp, and Thiele 2008 disaggregate aid into categories and use an instrumental variable approach that addresses some of the ambiguities 
in key votes that attract substantial attention from donors-because we know that the distribution of aid differs from need-based allocations, ${ }^{14}$ and is strongly related to the geopolitical interests and foreign policy preferences of the donors. ${ }^{15}$ In addition, a number of studies have found associations between UN voting and aid from the IMF and World Bank, and argue that the United States uses loans from those agencies to reward its allies. ${ }^{16}$

If democracies are not inherently more supportive of US positions than other states, is it instead the case that the United States targets them more frequently for influence attempts? Bueno de Mesquita and Smith argue the opposite. Taking a demand-side approach to foreign aid, they argue that aid should flow to the countries whose positions are least expensive to buy. Because autocrats are more willing to accommodate US preferences, they should receive the lion's share of the rewards. ${ }^{17}$ In contrast, we take a supply-side approach. In our view, the relevant political constraint on US foreign aid is political support in Congress for aid to particular countries. Because it is more popular to give aid to democracies than to autocrats, influence strategies are more credible when directed at democracies.

Foreign aid is supported by a coalition that includes members of Congress with altruistic and realpolitik motivations, and both sets of concerns are reflected in US foreign aid allocations. ${ }^{18}$ Democratic Party voters tend to support foreign aid that is need-based, development-oriented, delivered to countries with attractive political regimes, and channeled through international organizations; Republican Party voters generally prefer aid that is targeted to American strategic allies, that is connected to explicit foreign policy quid pro quos, and that is disbursed bilaterally. ${ }^{19}$ To achieve these multiple objectives, Congress has developed a detailed aid

in the previous literature, and find evidence in favor of a vote-buying hypothesis. Using an alternative identification strategy, Kuziemko and Werker 2006 narrow the interpretation of their empirical results by focusing on temporary membership in the UN Security Council, and find that US foreign aid increases significantly when a country becomes a temporary UN Security Council member, and drops off again after membership lapses.

14. See Boone 1996; and Collier and Dollar 2002.

15. See, for example, Maizels and Nissanke 1984; Boone 1996; Cashel-Cordo and Craig 1997; Schraeder, Hook, and Taylor 1998; Alesina and Dollar 2000; Alesina and Weder 2002; Svensson 1999; and Neumayer 2003.

16. See Thacker 1999; Oatley and Yackee 2004; Barro and Lee 2005; Stone 2004, 2008, and 2011; and Kilby 2013. UN voting is rapidly becoming recognized as an important control variable in studies that seek to explain participation in IMF programs, and as a useful instrument for selection-controlled studies of their effects, because UN voting is presumably exogenous with respect to outcome variables such as economic growth (Steinwand and Stone 2008). Thacker 1999 finds that increasing the similarity of a country's profile of votes in the UNGA to those of the United States over time is associated with a higher probability of IMF lending. Barro and Lee 2005 find that IMF loans are associated with similarity to US voting patterns in the UN and economic ties with the United States. Andersen, Harr, and Tarp 2006 use important UNGA votes to explain the probability that a country obtains an IMF program, Kilby 2013 uses important UNGA votes to explain the distribution of World Bank loans, and Dreher, Sturm, and Vreeland 2009 find that temporary membership in the UN Security Council increases World Bank loans.

17. See Bueno de Mesquita and Smith 2007 and 2009.

18. See Poe and Meernik 1995; Apodaca and Stohl 1999; and Demirel-Pegg and Moskowitz 2009.

19. See Milner and Tingley 2010 and 2013. 
appropriation process that allows members to influence foreign aid commitments but has also delegated substantial discretion to the executive branch to manipulate aid disbursements. The executive branch can use this discretion to buy votes in the UNGA, and the 1985 law authorizes it to do so. In practice, however, some deviations from appropriated levels are more politically costly than others, and more likely to motivate Congress to reduce executive discretion in the future. In particular, it may be controversial to provide foreign aid to autocratic countries, especially to those that engage in extensive repression or human-rights abuses, so when the State Department searches for a country whose vote it could buy by offering a short-term infusion of foreign aid, it looks first for democracies. As a result, democracies are more likely than autocracies to be rewarded when they vote in support of US positions.

On the other hand, the domestic politics of US foreign aid also ensures that it is costly to withhold aid that has been committed to autocratic countries. Because it is more controversial to aid autocracies, the set of autocracies that receive substantial aid commitments is limited to countries that play particularly important roles in US foreign policy. Recent examples include Egypt under Hosni Mubarak and Pakistan under Pervez Musharraf; examples during the Cold War included Zaire under Mubutu Sese Seko and the Philippines under Ferdinand Marcos. Many of these regimes take public postures that are critical of US foreign policy-in recent years, Pakistan and Egypt frequently voted against the United States in the UN-but they play important roles in US policy in other ways, often as regional anchors of US influence. In addition, foreign aid generally plays a key role in guaranteeing political stability in these fragile authoritarian states, so that withdrawing it could cost the United States a reliable regional supporter and bring a more oppositional regime to power. ${ }^{20}$ Under these circumstances, the credibility of US threats to withdraw support over acts of symbolic defiance would be limited, and such threats are rarely made. ${ }^{21}$

We argue against the hypothesis that democracies vote with the United States because they share common values. On the contrary, we claim that the pattern arises because democracies are more likely to be punished or rewarded for their votes. Disentangling the hypothesized effects requires that we simultaneously estimate voting preferences, target country susceptibility to influence attempts, and the credibility of those attempts, so we turn next to this problem.

\section{A Strategic Estimator for UN Voting}

Previous studies of UN voting have been unable to disentangle strategic and sincere voting because they have not explicitly modeled voting as a strategic choice. There are two important methodological issues to address. First is the familiar problem of endogeneity, and the substantive concern is that UN voting may be associated with 
US aid either because countries comply with US preferences to obtain aid, or because countries that sympathize with US positions in the UN are likely to receive aid irrespective of how they vote. Our approach deals with this particular endogeneity problem by estimating equations for US aid allocations and for UN voting decisions and by making identifying assumptions, as in an instrumental variables approach, but it takes advantage of the strategic structure of the model as part of the identification strategy. The second issue is strategic misspecification bias, and the substantive concern is that the relationships among preferences, voting, and aid allocations may depend on strategic calculations. In particular, we argue that the credibility of US influence strategies vary systematically across countries, which affects the relationship between aid and UN voting. Estimators that fail to account for how the US influence strategy induces strategic recipient behavior will be biased and inconsistent; the effect is equivalent to omitted variable bias..$^{22}$

Strategic effects are important because the effectiveness of US influence attempts depends on their credibility. Suppose that the United States threatens to reduce aid to a developing country if it votes against the US position on an important vote, and we observe that the country defies the US demand. Two inferences are possible. It may be the case that the country's leadership is highly motivated to resist US policy preferences. Alternatively, the government might not be strongly opposed to the US position, but the leadership might calculate that the US threat is unlikely to be carried out. It is impossible to accurately estimate either government preferences or the effectiveness of influence attempts without considering how key variables influence credibility. Consequently, we use a strategic choice model that can capture this effect.

The structure of the statistical model we estimate is depicted in Figure 1. First, the recipient country decides whether to vote for or against the US position. If the recipient votes against the United States on an important vote, the United States decides whether to punish it with significant aid reductions. If the recipient's vote coincides with the US position, the United States chooses whether to reward it with a significant increase in aid flows. ${ }^{23}$ The model imposes the simplest possible structure that allows for strategic voting and for threats and promises to be linked to aid flows. ${ }^{24}$

The formal model predicts that each actor chooses the action at each node that yields the highest expected utility. To convert the formal model into a statistical model, we add a stochastic component to the utilities of the actors, which gives us a probability

\section{Signorino and Yilmaz 2003.}

23. Aid disbursements fluctuate for a variety of reasons that are not related to UN voting, so it would not be appropriate to use the difference between commitments and disbursements as a direct measure of punishments and rewards. Instead, we estimate an equation for predicted disbursements that includes current commitments, lagged disbursements, and fixed effects, which has an R-squared of .99. We specify punishments and rewards as dichotomous, and we use the conservative strategy of coding a case as a punishment or reward only if it is outside the 95 percent confidence interval. The discussion of our dependent variables provides more details.

24. It is also possible to model vote choice as multinomial, where a recipient can (1) vote in strict accordance with the United States, (2) abstain from the vote, or (3) vote against the United States. This model is considerably more complicated and does not seem substantively warranted. 
distribution over the four possible outcomes of the model. We characterize this disturbance as agent error, which seems appropriate to our context. ${ }^{25}$ Agent error might occur in the voting stage, for example, because the UN ambassador is not informed, or not informed in a timely manner, of the preferences of the leader, or because disagreements within the government give ambassadors discretion to vote their own preferences. Agent error might occur at the disbursement stage because of a disagreement between the executive and legislative branches of government, because of an interagency dispute, or because of some other intervening variable that is orthogonal to UN voting, such as the recipient country's policies regarding human rights, trade, or the environment.

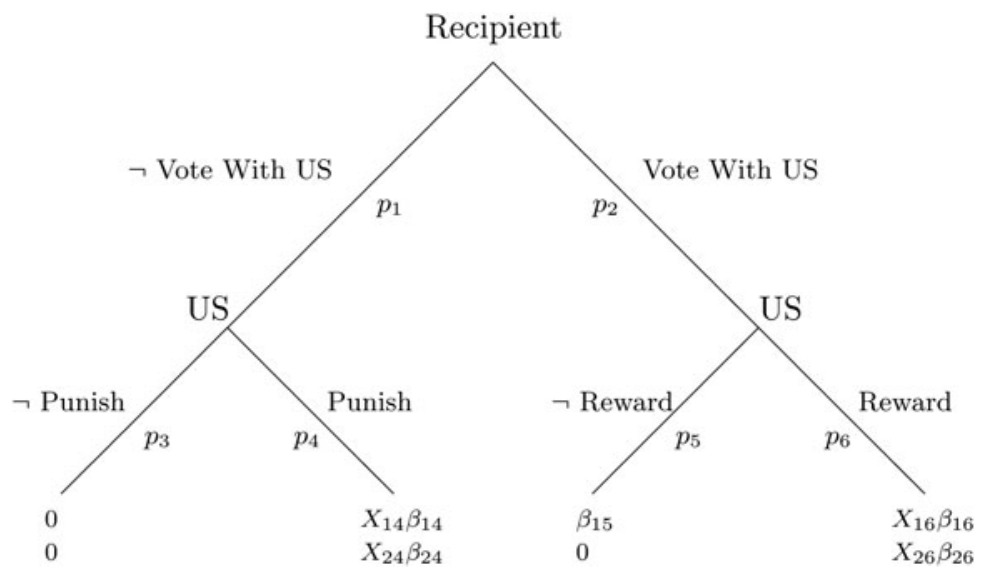

FIGURE 1. The Voting-Aid Game

The recipient and the United States make decisions in the game by weighing their expected utilities for each possible action. The model explicitly allows the recipient's voting decision to be influenced by the expected effect it will have on aid flows. We start from the last move in the game, the US decision to punish, reward, or do nothing in response to the recipient's vote, and move up the game tree to show the players' expected utility calculations. For each vote, or observation, $i=1 \ldots n$, the recipient decides whether to vote for or against the US position. If the recipient does not vote with the United States, the United States makes the following comparison: ${ }^{26}$

$$
\begin{aligned}
p_{i, 4} & =\left[E U_{U S}^{*}(\text { Pun } \mid \text { Disagree })>E U_{U S}^{*}(\neg \text { Pun } \mid \text { Disagree })\right] \\
& =\left[E U_{U S}(\text { Pun } \mid \text { Disagree })+\varepsilon_{4}>E U_{U S}(\neg \text { Pun } \mid \text { Disagree })+\varepsilon_{3}\right] .
\end{aligned}
$$

26. Note that Pun stands for punish, Rew for reward, Agree for agreement with the US position, and Disagree for disagreement with the US position. The numbers on the probabilities and $\varepsilon$ terms correspond to the numbers assigned to the players' actions in Figure 1. 
Assume the $\in$ terms are independent and identically distributed (i.i.d.) Type 1 Extreme Value, which yields:

$$
\begin{gathered}
p_{i, 4}=\frac{\exp ^{U_{\text {US }}(\text { Pun } \mid \text { Disagree })}}{\exp ^{U_{\text {US }}(\text { Pun } \mid \text { Disagree })}+\exp ^{U_{\text {US }}(\neg \text { Pun } \mid \text { Disagree })}} \\
p_{i, 3}=1-p_{i, 4} .
\end{gathered}
$$

In deciding whether to reward the recipient when the recipient votes in agreement, the United States makes a similar comparison that leads to expressions almost identical to those in Equations (1) to (4). The recipient makes its decision to vote with the US position or not by calculating, with some error, its utility for voting in agreement or disagreement with the United States. The recipient's utility is a function of its preferences over outcomes and the probability that the United States will subsequently reward or punish. The comparison of the expected utilities for voting for or against the US position take the following form:

$$
\begin{aligned}
p_{i, 2} & =\operatorname{Pr}\left[E U_{R}^{*}(\text { Agree })>E U_{R}^{*}(\text { Disagree })\right] \\
& =\operatorname{Pr}\left[E U_{R}(\text { Agree })+\varepsilon_{2}>E U_{R}(\text { Disagree })+\varepsilon_{1}\right]
\end{aligned}
$$

If we again assume that the $\epsilon$ terms are i.i.d. Type 1 Extreme Value, we obtain the following:

$$
\begin{aligned}
& p_{i, 2}=\frac{\exp ^{\left(p_{i, 6} U_{R}(\text { Agree }, \text { Rew })+p_{i, 5} U_{R}(\text { Agree }, \neg \text { Rew })\right)}}{\exp ^{\left(p_{i, 6} U_{R}(\text { Agree }, \text { Rew })+p_{i, 5} U_{R}(\text { Agree }, \neg \text { Rew })\right)}+\exp ^{\left(p_{i, 4} U_{R}(\text { Disagree }, \text { Pun })+p_{i, 3} U_{R}(\text { Disagree }, \neg \text { Pun })\right)}} \\
& p_{i, 1}=1-p_{i, 2} .
\end{aligned}
$$

We utilize the statistical backwards induction (SBI) technique developed by Bas, Signorino, and Walker. ${ }^{27}$ The SBI technique is employed by separately estimating the logit equation for each possible decision in the game rather than simultaneously estimating the full system of equations. First, we estimate the probability that the United States punishes a recipient for disagreement, that is, $p_{i, 4}$. As indicated in Equation (2) above, $p_{i, 4}$ is a function of the US utility for punishing the recipient following disagreement, which we estimate with substantive variables, that is, $X_{24} \beta_{24}$. approach. 
The United States compares its utility for punishing disagreement in each case $\left(X_{24} \beta_{24}\right)$ with its utility for not punishing disagreement $\left(\beta_{23}\right)$. The probability the United States rewards agreement, that is, $p_{i, 6}$, is estimated analogously, relative to not rewarding agreement. Second, we estimate the probability that the recipient votes with the US position, that is, $p_{i, 2}$. The probability of agreement with the United States is a function of the recipient's utilities over all possible outcomes in the game, weighted by the probability that each outcome will prevail—that is, Equation (7). The probabilities that the US will punish disagreement or reward agreement are obtained from the first-stage logit regressions (that is, $p_{i, 3}-p_{i, 6}$ ). SBI is attractive in our context because it ensures that the likelihood is concave, so our results reflect the true maximum likelihood estimate. In addition, computational time is decreased significantly relative to simultaneous estimation of the full system of equations. The disadvantage of SBI is that the standard errors in the recipient's estimates are biased downward because the probabilities are treated as fixed data. Following the recommendations of Bas, Signorino, and Walker, we correct the standard errors using the bootstrap. Although the standard errors for the US utilities are not affected by this issue, we also bootstrap them to be conservative. For each model, we run 500 bootstrap iterations.

We take several steps to ensure that the fact there are multiple important votes in each year is not a problem for our analysis. First, we sample by year when we calculate the bootstrapped standard errors to ensure that the standard errors are not affected by the lack of independence among votes in each year. ${ }^{28}$ Second, to ensure that including multiple votes in each year does not bias our coefficients, we randomly sample one vote from each year for each recipient country in the sample and estimate our model on this reduced set of votes. This leads to a sample size that is roughly 15 percent the size of the overall sample, but our key results are robust to this procedure. Thus, including multiple votes per year does not appear to affect either our standard errors or estimates in any substantial way. ${ }^{29}$

We specify the utilities of the recipient and the United States with some of the same variables. Consequently, to identify the model both the recipient and the United States must have the utility normalized to 0 for at least one outcome that is possible at its initial information set and affects its utility. ${ }^{30}$ In addition, no regressor can be estimated in every utility. We normalize the recipient's utility for not being punished after voting in disagreement (a sincere opposition vote with no consequences) to 0 . For the United States, we normalize the utilities for not punishing the recipient following a vote against the United States and for not rewarding the recipient following a vote in agreement (harmony) to 0 . Thus, all estimated coefficients for each player in each of the remaining utilities are interpreted relative to these outcomes. Normalization of a player's utility for one possible outcome in the strategic logit

28. This is analogous to estimating clustered "robust" standard errors, although it often yields more conservative estimates. We also tried sampling by vote, which yields similar results.

29. The results of this robustness check are included in the supplemental appendix.

30. An initial information set for each player is the node at which it makes its first move in the game. 
model is analogous to the standard method of identifying a multinomial logit model. This model captures strategic voting and allows threats and promises about important UNGA votes to be linked to aid flows.

\section{Data}

We use data on aid flows from the United States, voting by the United States and US aid recipients in the UNGA, and data on other variables of interest. The data on aid flows from the United States to potential recipients are published by the Organisation for Economic Cooperation and Development (OECD) Development Assistance Committee and cover 1966-2001. The data include both Official Development Assistance (ODA) and Official Assistance (OA) disbursements in millions of US dollars.

We use the Documenting Votes in the UN General Assembly, v2.0 data set compiled by Voeten, and we focus on votes defined as important by the State Department in its annually published Report to Congress on Voting Practices in the United Nations. ${ }^{31}$ The temporal domain for the voting data starts in 1984, the year in which US law first required the State Department to report how countries vote on issues that are regarded as important to US interests. The aid disbursement data are measured one year after the votes take place, which makes the temporal range 1985 to 2001. The vast majority of UN votes take place in the last months of the year, so it would be inconsistent with the structure of the model to use data on voting and aid from the same year. ${ }^{32}$ The United States has never been absent for important votes. Votes in which the recipient country is absent are excluded. ${ }^{33}$

\section{Regressors}

We use several regressors to estimate the utilities of the recipient countries and the United States over the outcomes in the model, including variables specific to the recipient country and variables that characterize the recipient's relationship with the United States. ${ }^{34}$ Our primary quantity of interest is the effect of democracy, which we measure using Polity IV scores in the main results, and using a dichotomous measure ${ }^{35}$ as a robustness check..$^{36}$ Our identification assumptions are not restrictive, so we capture the effect of each regressor on each choice. This allows

31. Voeten 2005.

32. We thank an anonymous reviewer for reminding us to highlight this.

33. We thank Jun Xiang, who extended the Voeten data to include all important votes and shared his data with us, and Christopher Kilby, who provided the data used in Kilby 2013 for comparison. We compared the two data sets and found few differences.

34. A table with descriptive statistics is presented in the appendix.

35. Alvarez et al. 2000.

36. We replicated our results using the dichotomous measure of democracy introduced by ACLP and updated by Cheibub, Gandhi, and Vreeland (2010) and found no substantive differences in our results. 
democracy to affect the recipient's utilities for voting with or against the United States to capture the coincidence of interests hypothesis, the recipient's utilities for being punished or rewarded to capture hypotheses about the compliance or recalcitrance of democratic states, and the US utility for punishing or rewarding to capture the credibility hypothesis. Two variables specific to the recipient are gross domestic product (GDP) per capita in 1996 US dollars ${ }^{37}$ We expect the level of development to affect the domestic incentives for aid recipients to take foreign policy positions, their vulnerability to US pressure, and the amount of resources required to effectively coerce them. Similarly, we expect the political orientation of the government to reflect its preferences to support or oppose the United States and its willingness to resist US pressure, and also to affect the attractiveness of using sanctions or rewards from the US point of view. To measure the political orientation of the executive, we create two binary variables that indicate whether a recipient country's executive was left of center and whether it was right of center, respectively. The excluded category includes governments that are centrist and those whose orientations are not clear. ${ }^{38}$

Interdependence may affect domestic preferences over foreign policy, vulnerability of recipients to influence, and the cost of attempting to exert influence. We measure interdependence in terms of bilateral trade flows in millions of 1996 US dollars and a variable that indicates whether the recipient has an alliance with the United States. ${ }^{39}$ We expect high levels of trade to reflect close diplomatic relations. In addition, countries that are highly dependent on trade with the United States should be more vulnerable to influence attempts, but interdependence should also make them more expensive to punish or reward, making them less attractive targets from the US point of view. Similarly, we expect allies to have similar preferences to the United States and to be vulnerable to influence attempts because of the intensity of bilateral ties, but to be unattractive targets for punishment or rewards because of security externalities. $^{40}$

Finally, our model captures the specific characteristics of particular votes, by including a variable that indicates whether the United States voted "No." "Yes" and "No" votes are qualitatively different, because UNGA proposals almost always pass, so "No" votes find the United States in the minority, and usually badly isolated. In the late 1970s, after the United States lost control of the UNGA agenda to the Group of 77, the United States began to vote "No" on most roll calls, where it had previously cast a majority of "Yes" votes. The United States voted "No" on almost

Polity scores are most likely to be problematic when the dependent variable measures some form of internal violent conflict, which is not the case here. For details, see Vreeland 2008.

37. See Russett and Oneal 2001; Oneal and Russett 2005, and the political orientation of the executive.

38. Keefer 2007.

39. Oneal and Russett 2005.

40. We also estimate a model with a variable that indicates whether the US president is a Democrat or a Republican. This variable has an insignificant coefficient, and its inclusion does not alter any of the key results. 
75 percent of State Department-identified important votes in the sample. We include a binary variable for each vote, which identifies whether the United States voted "Yes" or "No." Thus, we are essentially including a kind of vote-specific fixed effect, which allows us to isolate variation in the other regressors within the substantively comparable vote type. This makes sense because the pattern of punishment and rewards should vary across vote type, since agreement is more common on "Yes" votes. Accordingly, if voting is strategic the effect of key variables on recipient voting behavior will also vary with vote type. ${ }^{41}$

\section{Dependent Variables}

Our dependent variables measure whether countries voted with or against the US position on important votes in the UNGA and whether there were subsequent significant deviations of US aid disbursements from the trend. First, we utilize voting records on important votes and create a binary variable that is coded 1 if the votes of the United States and the recipient country coincide on a particular vote, and 0 otherwise..$^{42}$

The important votes are distributed across fourteen frequently occurring issues and numerous less frequent ones. ${ }^{43}$ Many of the important votes are specific to countries that have played a key role in US foreign policy, for example, Iraq, while others address policy areas, for example, weapons of mass destruction (WMD). However, there is no one issue that dominates the set of important votes. Although issues related to Israel and Palestine are among the most frequent, comprising more than 15 percent of the votes, several other issues receive a similar degree of attention. Human rights issues occur most frequently, making up almost 25 percent of the votes.

Next we code one variable to indicate whether the United States punished the recipient with a significant aid reduction, and a second to indicate whether the United States rewarded the recipient with a significant increase in disbursement. For this purpose we could have used a naive punishment variable, such as one that takes a value of 1 if aid disbursements in a given year are lower than aid commitments. However, such a measure would include numerous false positives, because aid disbursements differ from commitments for a variety of reasons that are unrelated to UN voting, for example, an increase in anti-US terrorist attacks. ${ }^{44}$ Instead, we choose a conservative coding strategy to avoid imputing political motivations to random fluctuations, coding "punishments" and "rewards" only when aid

41. We test whether inclusion of this variable is merited with likelihood ratio (LR) tests. LR tests easily show that our model specification is improved with inclusion of the variable. Additionally, inclusion of this variable significantly improves the predictive power of the model. However, if we separately estimate regressions on "Yes" and "No" votes, we recover results that are not substantively different.

42. We treat "Abstain" as agreement with the US position, as the United States works hard in many cases to get countries to abstain on particularly sensitive issues. Although we think this is the right choice substantively, we also tried treating abstentions as disagreements and did not find markedly different results. See the appendix for these alternative results.

43. See the appendix for details about the distribution of votes across issues.

44. Boutton and Carter 2014. 
disbursements fall outside the 95 percent confidence interval of the level predicted by a forecasting model..$^{45}$ We predict aid disbursement for each country in each year with a lagged dependent variable, country fixed effects model, using the full time-series of aid disbursement data from 1966-2001. The procedure is fully explained in the appendix along with a discussion of several potential methodological concerns. ${ }^{46}$

This approach has important advantages. We use aid commitments to predict disbursements, so our variables can be interpreted as discretionary deviations by the executive branch from appropriated aid levels. ${ }^{47}$ In addition, our estimation procedure controls for temporal trends in disbursement, and the recipient country fixed effects control for unobserved country-level effects without unnecessarily complicating our main model. Our approach is scale invariant, so the construction of the dependent variable does not lead to spurious inferences, for example, that countries that receive relatively high levels of aid (for example, Israel) are more or less likely to receive punishments or rewards. The model explains the variation in yearly aid disbursements across recipients very well $(\mathrm{R}$-squared $\approx 0.99)$, but more variance in aid disbursements remains to be explained for each recipient over time (R-squared $\approx$ $0.53)$. The correlation between predicted and actual aid disbursements is 0.85 . Punishments and rewards are rare under our coding procedure, representing 3 and 2.4 percent of the observations, respectively, because we have defined them conservatively. However, 4.6 percent of countries that vote against US positions on important votes are coded as receiving punishment, and 7 percent of countries that vote with the United States on important votes receive rewards.

\section{Results}

The results of the full strategic model are presented in Table 1 . The model correctly predicts more than 84 percent of the observations, which is an improvement of 34

45. Type I errors-falsely classifying nonpunishment/reward episodes as punishments or rewards—are a greater threat to inference in our application than the opposite mistake, or Type II errors, because failing to identify some punishments or rewards that actually took place simply decreases the variance of our quantities of interest, making it more difficult for us to observe significant effects. Another way of thinking about this is that a 95 percent confidence interval implies that we are analyzing large rewards and punishments (relative to expectations), rather than rewards and punishments of all sizes. The larger the reward/ punishment, the more confident we are that it did not arise by chance; but it could also be the case that smaller rewards or punishments are generated by qualitatively different mechanisms. If so, we prefer to focus on the most important cases.

46. We replicated the analysis using 90 and 99 percent confidence intervals as robustness checks and derived the same qualitative results. We also reproduce our punishment and reward variables using aid disbursement data from 1975-2001 and from 1980-2001 only, to ensure that the results are not dependent on allocation patterns from 1966-79. The results using this alternative punishment and reward variables are very similar to those reported in the main text. We report the results using the post-1975 aid data and the different confidence interval thresholds in the appendix.

47. A potential concern is that our procedure might code countries as receiving rewards disproportionally when aid commitments are zero. In fact, however, we find that reward is less likely in cases of zero aid commitment than in cases where the United States has made a commitment. There are only thirty-eight zero commitment/reward observations in the data, and excluding them does not affect the results. 
TABLE 1. Utilities for statistical strategic model

\begin{tabular}{|c|c|c|c|c|c|}
\hline & $U_{R}$ (Punish) & $U_{R}(\neg$ Reward $)$ & $U_{R}($ Reward $)$ & $U_{U S}($ Punish $)$ & $U_{U S}($ Reward $)$ \\
\hline Constant & $62.63 *(8.42)$ & $-5.79 *(0.69)$ & & $-1.91 *(0.40)$ & $-2.85 *(0.21)$ \\
\hline RECIPIENT POLITY & $-3.50 *(0.35)$ & & $-0.63 \quad(0.50)$ & $0.05 *(0.01)$ & $0.10 *(0.02)$ \\
\hline ALLIES & $0.04 \quad(3.69)$ & & $-9.91 *(1.51)$ & $0.19(0.13)$ & $0.07 \quad(0.35)$ \\
\hline RECIPIENT GDP & $8.31 *(1.12)$ & & $-0.34 *(0.14)$ & $-0.09(0.16)$ & $0.02(0.03)$ \\
\hline TRADE & $3.05 *(1.13)$ & & $1.73 *(0.55)$ & $-0.05^{*}(0.02)$ & $-0.08 \quad(0.06)$ \\
\hline LEFT-WING EXECUTIVE & $1.08(3.88)$ & & $2.65 \quad(2.47)$ & $-0.07 \quad(0.11)$ & $-0.54 *(0.21)$ \\
\hline RIGHT-WING EXECUTIVE & $38.46^{*}(5.88)$ & & $10.40 *(4.19)$ & $-0.71 *(0.15)$ & $\begin{array}{ll}-0.43 & (0.29)\end{array}$ \\
\hline US VOTES NO & $-1.50 *(0.46)$ & & $-0.56(0.51)$ & $-0.08 *(0.03)$ & $0.02 *(0.01)$ \\
\hline
\end{tabular}

Notes: Bootstrapped standard errors in parentheses. Number of observations $=14,337$. Number of countries $=136$.

Time period $=17$ years. Percent correctly predicted: $84.9 \%$. Modal percent correctly predicted: $63.2 \%$. $*$ Significance at the .05 level.

percent over predicting the modal category. All of the columns of coefficients result from the same underlying theoretical model, and each column in the table contains the estimates for either the recipient's or the US utility for a particular outcome. For example, the first column contains the estimates for the recipient's utility for being punished after voting in disagreement with the United States. These effects are measured relative to the outcome in which the recipient votes against the US position without being punished, so they can be interpreted as the cost or benefit of punishment (when all other variables are at their mean). The fourth and fifth columns contain estimates for the US utility for punishing and rewarding, respectively. These effects are measured relative to the outcomes in which the recipient votes against the US position without being punished and in which the recipient votes for the US position without being rewarded, respectively. Therefore, these estimates can be interpreted as the cost or benefit to the United States of punishing or rewarding. In what follows, our discussion of these results primarily draws on the substantive effects reported in Table 2 and Figure 2, because the substantive effects are not straightforward to interpret from the estimated coefficients in Table $1 .{ }^{48} \mathrm{We}$ first discuss the US utility for punishing and rewarding, and then move up the game tree to discuss consequent recipient behavior.

48. The coefficients for US utilities are interpreted as would be the case in typical logit models. Thus, the sign is indicative of the direction of the effect on predicted probabilities. However, interpretation of the coefficients for recipient behavior without examining predicted probabilities is more difficult. This is the case because each coefficient reflects both the direct effect of a variable on the recipient's utility, as well as an indirect effect via the effect the variable has on the US propensity to punish or reward voting compliance. Because the same variables are included in both US and recipient utilities, the effects of key variables such as democracy can exhibit interaction effects. Although there are no interactive terms among the covariates, there are nevertheless interaction effects in the estimation of recipient utilities because the expected utility for each recipient country is the product of its own utility for each outcome and the probability that it will occur, which depends on how variables affect US strategies. 
TABLE 2. Marginal effects of regressors on US and recipient choices

\begin{tabular}{|c|c|c|c|c|c|c|}
\hline & \multicolumn{4}{|c|}{ US punishment and reward decision } & \multicolumn{2}{|c|}{ Recipient voting decision } \\
\hline & $\begin{array}{c}P r \\
\text { (punish) }\end{array}$ & $\begin{array}{c}\% \text { change in } \\
\operatorname{Pr}\end{array}$ & $\begin{array}{c}P r \\
\text { (reward) }\end{array}$ & $\begin{array}{c}\text { \% change in } \\
\operatorname{Pr}\end{array}$ & $\begin{array}{c}\operatorname{Pr} \text { (vote with } \\
\text { US })\end{array}$ & $\begin{array}{c}\% \text { change in } \\
\operatorname{Pr}\end{array}$ \\
\hline Median values & 0.047 & NA & 0.067 & NA & 0.125 & NA \\
\hline Polity $=-9$ & $0.028 *$ & $-40 \%$ & $0.032 *$ & $-52 \%$ & $0.071 *$ & $-43 \%$ \\
\hline Polity $=7$ & $0.078 *$ & $+66 \%$ & $0.137 *$ & $+104 \%$ & $0.097 *$ & $-22 \%$ \\
\hline Alliance $=1$ & 0.051 & $+9 \%$ & 0.072 & $+7 \%$ & $0.091 *$ & $-27 \%$ \\
\hline Recipient $G D P=1,000$ & 0.054 & $+15 \%$ & 0.064 & $-4 \%$ & $0.075 *$ & $-40 \%$ \\
\hline Recipient $G D P=12,000$ & 0.028 & $-40 \%$ & 0.082 & $+22 \%$ & $0.237 *$ & $+90 \%$ \\
\hline Trade $=\$ 15$ million & $0.047 *$ & $+0 \%$ & 0.067 & $+0 \%$ & $0.125 *$ & $+0 \%$ \\
\hline Trade $=\$ 10$ billion & $0.044 *$ & $-6 \%$ & 0.062 & $-7 \%$ & $0.122 *$ & $-2 \%$ \\
\hline Left-wing & 0.044 & $-6 \%$ & $0.062 *$ & $-7 \%$ & 0.113 & $-10 \%$ \\
\hline Right-wing & $0.025^{*}$ & $-47 \%$ & 0.045 & $-33 \%$ & $0.091 *$ & $-27 \%$ \\
\hline Yes vote & $0.101 *$ & $+115 \%$ & $0.054 *$ & $-19 \%$ & $0.963 *$ & $+670 \%$ \\
\hline Polity $=-9$ & $0.061 *$ & $-40 \%$ & $0.025^{*}$ & $-54 \%$ & $0.882 *$ & $-8 \%$ \\
\hline Polity $=7$ & $0.161 *$ & $+59 \%$ & $0.111 *$ & $+106 \%$ & $0.994 *$ & $+3 \%$ \\
\hline
\end{tabular}

Note: * indicates statistical significance.

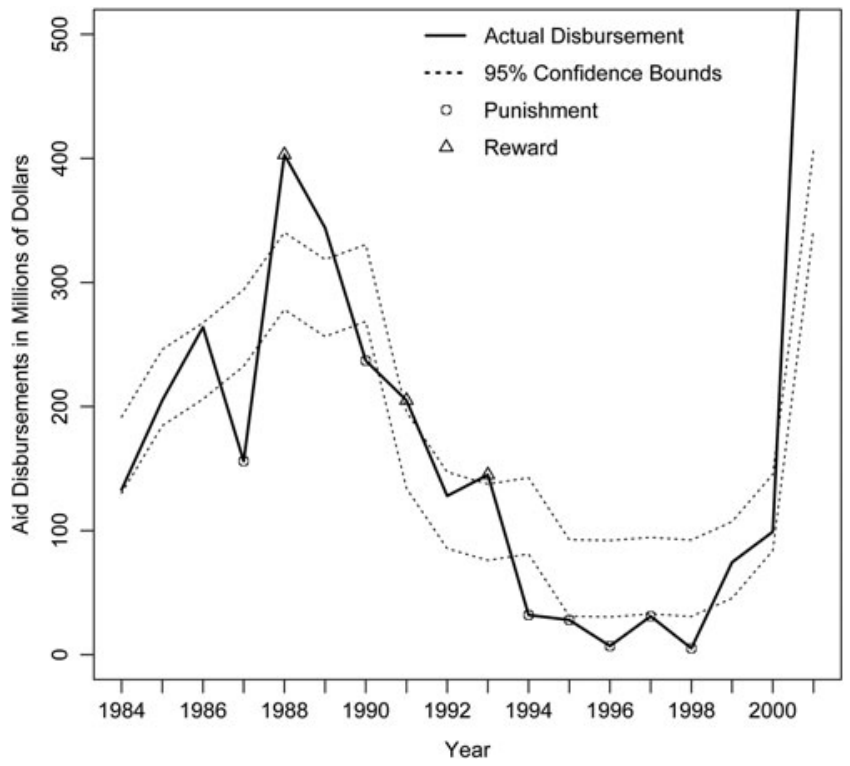

FIGURE 2. Aid Flows to Pakistan, 1984-2001

\section{Punishments and Rewards: US Behavior}

Table 2 contains the probability that the United States punishes following disagreement and rewards following agreement at various levels of the variables. The first row of 
Table 2 shows the conditional probability of punishment or reward when all variables are held at their median values, and each subsequent row alters the value of one variable to isolate its effect on the predicted probabilities. Thus, the second row shows the probability of punishment and reward when the recipient is a highly autocratic country (Polity score $=-9$ ) and all other variables are held at their median values. Specifically, the third column of Table 2 shows the percentage change in the probability of punishment relative to the median case (that is, the first row). Columns (4) to (5) repeat this procedure for the probability that the United States rewards the recipient country when it votes in agreement. Thus, the second row indicates that a highly autocratic recipient is 40 percent less likely to be punished if it opposes the United States and 52 percent less likely to be rewarded if it cooperates than in the median case (Polity score $=-1$ ). The third row indicates that a democracy (Polity score $=7$ ) is 66 percent more likely to be punished when it votes against the United States and 104 percent more likely to be rewarded when it votes in support than the median case. The final two columns show the predicted probabilities that the recipient will vote with the US position (column 6) and the associated percentage change in probability (column 7).

The low baseline predicted probabilities in the first row of Table 2 reflect the fact that we have defined our reward and punishment variables conservatively. The choice of carrots or sticks depends on whether the United States votes "Yes" or "No," and the different US strategy reflects a basic difference in the kinds of issues on which the United States finds itself in the minority. The 26.5 percent of important votes on which the United States votes "Yes" pass by large margins; on the other hand, when the United States votes "No," it is usually badly isolated. In the baseline case, when the United States votes "No" because it is in the minority, the probability that the United States punishes a country that deviates from the preferred US position is 0.047 when all variables are held at their median or mean, while the probability that it rewards compliance is 0.067 . In contrast, when the United States votes in favor of a resolution, voting against the US position is less common. This makes punishment more feasible, because there are few countries to punish, and the countries that vote in the minority are isolated in their opposition. Furthermore, "Yes" votes tend to allow the United States to take the high moral ground, defending widelyheld principles, whereas "No" votes often occur on resolutions that compel it to defend unpopular positions. Accordingly, the United States is much more likely to punish opposition to its "Yes" votes—doing so in 10 percent of baseline cases-and is slightly less likely to reward agreement when it is already widespread in the assembly. The United States is more likely to use carrots than sticks when it is trying to defeat a resolution, and more than 100 percent more likely to use sticks rather than carrots when it is rounding up support for one. In the final three rows of Table 2, we demonstrate the effect of "Yes" votes for the median recipient and for a democracy and autocracy. The distinction between "Yes" and "No" votes is one that the literature has not previously made, perhaps because it has not distinguished between punishments and rewards.

Our central results reveal that the United States conditions its behavior on regime type in significant ways. The results in Table 2 indicate that US promises and threats 
to condition aid on UN voting are most credible when directed toward democracies. The United States is reluctant to punish autocracies, perhaps because they are more dependent on aid flows to maintain power, ${ }^{49}$ and they receive aid in the first place only if they are important to US foreign policy. ${ }^{50}$ The United States is also reluctant to reward autocracies with increased aid, perhaps because giving aid to dictators is unpopular in Congress. These findings stand in contrast to the argument of Bueno de Mesquita and Smith that US vote-buying strategy is directed primarily at authoritarian countries because their narrow bases of support make it less expensive to purchase policy concessions from them. ${ }^{51}$ If this were the case, autocracies should be most likely to be punished when they oppose the United States and rewarded when they comply; but we find that democracies are more likely to be punished for noncooperation and rewarded for cooperation. It is a striking finding that the United States is less nimble in its use of aid to reward and punish autocracies, and as we discuss, this makes them less supportive of US positions. The present analysis cannot offer a direct test of alternative mechanisms to explain this finding, but our conjecture is that aid to autocracies is tied to particular, long-term policy goals such as regional stability or military basing rights, and is provided primarily to prevent regime change. If this is the case, it could be excessively costly to use this aid to influence UN voting. 52

Plotting the marginal effects of the variables allows us to probe a bit further. Figures $3 \mathrm{~A}$ and $3 \mathrm{~B}$ plot the effects of varying development and regime type simultaneously. ${ }^{53}$ The estimates indicate that a low level of development makes punishments more likely and rewards less likely. The marginal effects reported in Table 2 indicate that when all other variables are at their medians, poor countries are more likely to be punished than middle-income countries when they oppose the US position. This suggests that punishments are less costly to apply to weak countries, which are unable to retaliate, and the United States prefers to use positive incentives with more developed countries that are better able to resist. Figure 3A illustrates the effect of per capita GDP on punishment while allowing polity scores to vary, and also illustrates the effect of democracy, which makes punishment more likely. The slope of the effect of democracy on punishment is steeper when countries are poor, which is consistent with the interpretation that the US reluctance to punish authoritarian countries is related to poverty and high aid-dependence ratios.

Rewards have a similar interpretation, which reflects the fact that rewards and punishments are strategic substitutes. Table 2 indicates that the median middle-income

49. See Bueno de Mesquita et al. 2003; and Bueno de Mesquita and Smith 2010.

50. Schraeder, Hook, and Taylor 1998.

51. Bueno de Mesquita and Smith 2007.

52. An anonymous reviewer suggested the alternative interpretation that the United States has a budget constraint and simply prefers to buy the votes of democratic countries. This would account for the patterns of rewards that we observe, but not the patterns of punishments.

53. Because this is a nonlinear model, the marginal effects of our independent variables vary across the ranges of the other covariates. GDP per capita is measured in thousands of constant US dollars. 
country is much more likely than a poor country to be rewarded when it offers support, and consolidated democracies are over five times more likely to be rewarded than consolidated autocracies. Figure 3B shows that poor countries and autocracies are unlikely to be rewarded under any circumstances, but the effect of development on the probability of being rewarded increases as countries become more democratic, and the effect of being democratic is enhanced as countries become more developed.

The case of Nicaragua in the early 1990s illustrates the way in which the United States uses aid disbursements to punish and reward relatively poor democracies. In 1990, Nicaragua conducted multiparty elections that were won by the conservative opposition party, led by Violeta Chamorro. Because Nicaragua was a poor democracy (Nicaragua's Polity score was 6 in 1990), we expect both punishments and rewards to be more likely than in the average country. Nicaragua's GDP per capita hovered around $\$ 2,000$ in the early 1990s, which is well below the mean of $\$ 5,000$ in the sample, however, so our model predicts a preference for punishments over rewards. In 1991 the Chamorro government voted in support of the United States on resolution R/46/82A, which pertained to the Middle East peace process, and was rewarded. The United States had taken note of a much more cooperative Nicaraguan government, ${ }^{54}$ and subsequently released additional aid funds after observing cooperation in several areas as well as a rare instance of cooperation in the UNGA. In the following year, the Chamorro government took a more oppositional stance relative to US interests in the UNGA, voting against the US position on all but one important vote. Chamorro's opposition to US positions, including on votes involving Cuba, was apparently intended as part of an effort to build bridges to the Sandinista opposition. The sole exception was a resolution that the United States supported on the situation in Bosnia, which passed unanimously. In response to this lack of cooperation, the United States reversed its aid policy toward Nicaragua in 1992 and punished the Chamorro government with significant aid reductions. ${ }^{55}$ The same pattern continued into 1993, with Nicaragua voting against a number of important resolutions and the United States continuing to withhold aid. This reversal of fortune was particularly striking, given the history of US opposition to the preceding Sandinista government only a few years before.

Pakistan is a good case to illustrate the effects of regime changes on US aid strategy, because it experienced a transition to democracy and another back to autocracy within the time period we study. Pakistan was autocratic from 1984-87 (that is, Polity score of -4 to -7), was democratic from 1988-98 under Benazir Bhutto and Nawaz Sharif (that is, Polity score of 7 to 8), and reverted to autocracy after a coup led by Pervez Musharraf in 1999 (that is, Polity score of -6). The expectation of our model is that Pakistan should be punished and rewarded more frequently while a democracy than while it was authoritarian. Figure 3 shows that this is indeed the 
(a)

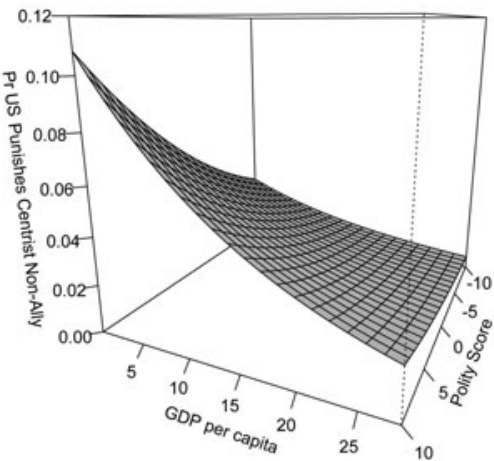

(c)

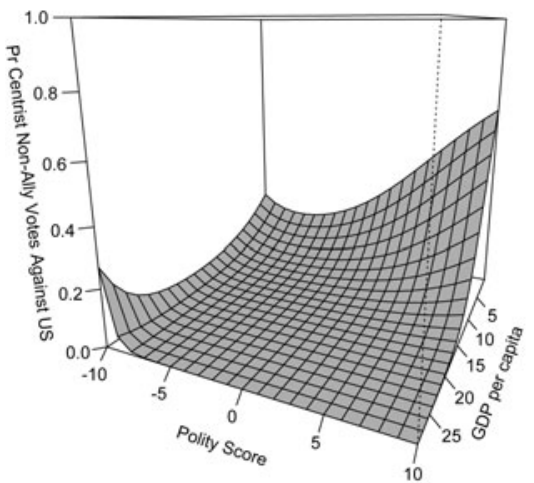

(b)

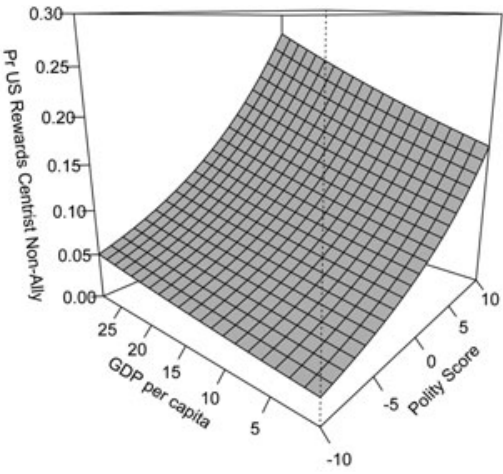

(d)

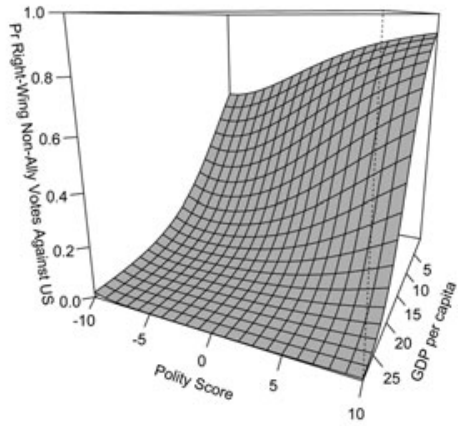

(e)

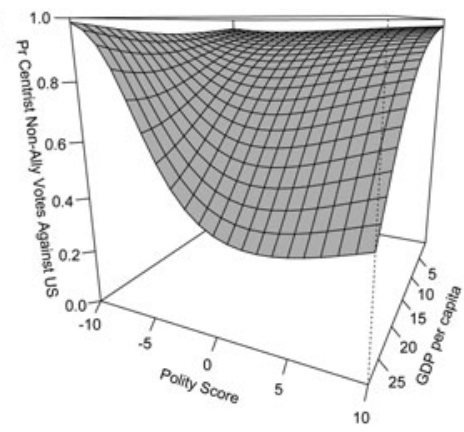

FIGURE 3. Democracy and Development

case. The United States punished or rewarded Pakistan in only one of seven years of nondemocratic government, while it punished (six times) or rewarded (three times) Pakistan during nine of the eleven years in which it was a democracy. ${ }^{56}$

56. Note that 2001, when Pakistan received substantial aid because of the US war with Afghanistan, is not coded as a reward because Pakistan's voting was uncooperative. 
Pakistan was a good candidate for punishment because it frequently voted against the US position on important issues. Pakistan voted with the United States position only 24 percent of the time, well below the sample mean of 35 percent. In the three years in which Pakistan was rewarded, it voted with the United States on several important votes that pertained to the Israeli-Palestinian conflict (for example, R/44/40A in 1988), and sided with the United States almost 35 percent of the time in 1988, 1991, and 1993. In contrast, during the six years in which it was punished, it voted with the United States only 23 percent of the time on important votes. Several of the votes identified as important by the United States during the mid-1990s condemned nuclear testing of the kind Pakistan was conducting. For example, Pakistan voted against R/53/77G in 1997, which was one of the most popular US-supported resolutions, opposed by only eight other countries.

\section{The Strategy of UN Voting: Recipient Behavior}

We now turn to a discussion of recipient behavior. The model allows for voting behavior to be strategic, because voting decisions precede aid disbursements. Consequently, vote choices depend both on governments' underlying preferences and on US disbursement strategies. The final two columns of Table 2 present the substantive effect of each regressor on the probability that the recipient votes in accordance with the US position, which can be thought of as the net effect of the regressor through the mechanisms of preferences, coercion, and vote buying. To tease out which mechanism is central to the voting behavior of democracies, we leverage the estimated coefficients, predicted probabilities for the recipient, and the predicted probabilities of US punishment and reward. The results provide ample evidence that US influence strategies affect voting. The results in Table 2 indicate that opposition to the United States is widespread on votes that it designates as important, but varies substantially depending on the US position on particular issues. As we discussed earlier, the baseline probability that an aid recipient votes with the United States when the US position is "No" is 0.125 , while the probability that an aid recipient votes "Yes" with the United States is $0.96 .{ }^{57}$ The United States voted "No" on approximately three-quarters of all votes that it defined as important. When the United States votes "Yes," it finds itself in the majority. These resolutions cover issues on which the United States takes less controversial positions and is able to craft a compromise that it is able to support. Since voting is very different on "Yes" and "No" votes, it is important to control for the US position, which determines the level and nature of recipient opposition and the US propensity to punish and reward recipients.

The raw data make clear that democracies are more supportive of the US position on important resolutions than autocracies for both "Yes" and "No" votes. We are now in a position to answer the question with which we began: Why are democracies more

57. Because "No" is the median position of the United States, the first row represents a "No" vote with all other variables at their median. 
supportive? Is this because democracies are more sympathetic to US policy positions, or because US influence attempts are more credible and effective among the set of democracies?

Our estimates indicate that democracies' preferences are inherently more oppositional than authoritarian governments' preferences. The negative coefficient of -0.63 for polity in the government's utility for being rewarded for compliance in Table 1 indicates that as a country becomes democratic, the net benefits of opposing the United States rather than complying and receiving rewards increase. (The reference category is voting in opposition with no consequences.) Although the coefficient is not statistically significant, the insignificant negative coefficient is inconsistent with the coincidence of preferences idea, which would predict a positive coefficient. ${ }^{58}$ This is also consistent with the interpretation that democracies in developing countries are more oppositional because their publics are critical of US positions, and democratically elected leaders have incentives to cast symbolic votes against the United States. It is difficult to sort out the aid recipients' motives-this coefficient could be interpreted to mean that democratic governments are less interested in receiving aid rather than more strongly opposed to US positions, for example-but the statistically significant and strong negative coefficient for polity in the utility for being punished suggests that this is not the case. Instead, when voting against US positions, democracies find aid suspensions more costly than do autocracies. If the net benefits of complying are still lower for democracies, this suggests that democratic governments more frequently oppose US policies. In any case, these results rule out the interpretation that the observed difference in voting behavior between democracies and autocracies is driven by greater willingness of democracies to comply with US preferences.

We can explore this intuition further using the predicted probabilities and the distinction between "Yes" and "No" votes. Recall that the United States is more likely to impose punishments when countries vote against it on "Yes" votes, since opposition to such popular measures tends to be isolated. In contrast, rewards are more likely for agreement on "No" votes, because the United States finds itself isolated on these resolutions. Accordingly, a recipient's vote with the United States on a "No" resolution is a much stronger indication of agreement because these reflect the most controversial and unpopular aspects of US foreign policy. On "No" resolutions, democracies are less likely to support the US position than mixed regimes (Polity $=-1$ ), despite being more likely to receive rewards when they do. In Table 2 we see that democracies support the US position on 10 percent of "No" votes, compared with 12.5 percent for mixed regimes, which make up the baseline case. This is inconsistent with the claim that having a democratic regime makes countries more likely to share US voting preferences. Very autocratic countries (Polity $=-9$ ) are the most likely to oppose the United States on "No" votes (supporting the US position in 7 percent

58. The bootstrapped coefficient when we do not sample by year is statistically significant, while the coefficient when we sample by year falls below conventional levels of significance. 
of cases). Although their incentives to take symbolic stands are weaker, they are least likely to receive rewards or punishments for their voting behavior.

On the other hand, punishment for deviating from the US position is more than twice as likely on "Yes" votes, and democracies are much more compliant under those circumstances. The probability that a democratic aid recipient is punished if it votes "No" on a "Yes" resolution is over 0.16. Democracies in fact support the United States with more than probability 0.99 on such resolutions, while autocracies, which are much less likely to be targeted by punishments, are much less likely to support the US position. The distinction between "Yes" and "No" votes underlines the importance of coercion. If coercion were not an important part of US strategy, it would be hard to account for the sharp differences between the treatment of democracies and autocracies. If democracies shared US preferences, there would be no need to tie punishments and rewards to voting behavior and recipients would not need to vote strategically. Indeed, on "No" votes, where the probability of punishment is low, democracies are less likely to support US positions; when the incentives to comply are weak, democratic governments reflect their constituents' interests.

We can provide a clearer picture of these relationships by varying some of the covariates that affect the probability that the United States employs punishments or rewards, and this is done in Figure 3. The logic of strategic interaction is made clear by jointly considering recipient voting behavior and US punishment strategies. The graphs in the lower half of Figure 3 depict the relationship between GDP per capita, regime type, and the probability of voting in opposition to the United States. Figure 3C and 3D depict the case of "Yes" votes. Aid recipients generally support the US position on important "Yes" votes, but relatively poor countries are increasingly likely to vote against the United States. Relatively authoritarian poor countries are highly compliant because they have few institutional incentives to oppose US positions. Opposition decreases among a wide range of democratic recipients, who are also likely to be punished for noncompliance. Only the very poorest and very democratic states are different because they still tend to oppose US positions at a high rate.

To illustrate the effect of coercion, the graph in Figure 3D replicates the graph in Figure $3 \mathrm{C}$, but alters one variable that affects the credibility of punishment. Recall that punishment is more likely than rewards for votes on resolutions that the United States supports, so punishment plays a key role in the calculations that deterred centrist democracies from voting against the United States in Figure 3C. In Figure 3D, however, the recipient is assumed to be right-leaning, and Tables 1 and 2 reveal that right-leaning governments are uniformly less likely to be punished when they defy the United States. The result, once the credibility of the US punishment strategy evaporates, is that poorer, right-leaning democracies are much more likely to vote their preferences: they are not deterred from opposing US positions. Changing the political orientation of the recipient to right-leaning greatly increases the probability that all poor states and all but the wealthiest democracies oppose the United States. This is a striking finding, since right-leaning governments are clearly not less likely than left-leaning ones to be sympathetic toward US policies. 
The effect is attributable to the fact that right-leaning governments are less likely to be punished when they vote their preferences.

Figure 3E depicts the case of "No" votes. Recall that punishments are rare when the United States votes "No," so strategic incentives rely heavily on rewards. Aid recipients are generally not supportive of the US position on "No" votes, but poverty makes countries increasingly likely to vote against the United States. Opposition by highly authoritarian governments is consistently high, as recipients with a Polity score of -10 or -9 are uniformly unlikely to receive rewards from the United States. As a recipient's government becomes more democratic, two countervailing effects race to affect the vote choice: less authoritarian governments are more likely to be rewarded for voting with the United States, but more democratic governments find doing so more distasteful. The result is a somewhat non-monotonic relationship between democracy and voting. The probability of opposition to the US position decreases as regimes move toward democracy, reaching its nadir among mixed regimes, and then increases gradually among the most democratic governments. The difference in the shape of the non-monotonic effects between the cases of "Yes" and "No" votes appears to be attributable to two factors. First, democratic publics find it more distasteful to support the US position on controversial "No" votes, where the United States is opposing the majority of countries. Second, punishments are generally unavailable to the United States during debates over resolutions that the United States opposes, so the incentives for democracies to conform are markedly weaker.

\section{Does Vote Buying Change with the End of the Cold War?}

Until this point we have presented results of a model that pools data from 1985 to 2001, but we now split the sample to ask whether the political economy of UN voting changed significantly with the end of the Cold War. The end of the Cold War might not be expected to substantially change the incentives of aid recipients, but it represented a sea change in US geopolitical strategy, so it would be surprising if there were no adjustments in aid policy. Indeed, it is often argued that foreign aid became more development-oriented with the end of the Cold War. ${ }^{59}$ We divided our sample into Cold War (1985-89) and post-Cold War (1990-2001) subsamples to test the robustness of our results, and found several differences in the samples that shed light on the interpretation of vote buying in the United Nations. ${ }^{60}$ Our main findings remain robust across both time periods, so we present the full results in the appendix and describe the key differences here.

There are no significant differences in our estimates of recipient preferences between the post-Cold War sample and the pooled model, which indicates that

59. Wright and Winters 2010.

60. We also code 1991 as being the last year of the Cold War and find very similar results. See the supplemental appendix for details. 
TABLE 3. Marginal effects of regressors on US punishment decision

\begin{tabular}{|c|c|c|c|c|}
\hline & \multicolumn{2}{|c|}{ Cold War US punishment decision } & \multicolumn{2}{|c|}{$\begin{array}{c}\text { Post-Cold War US punishment } \\
\text { decision }\end{array}$} \\
\hline & $\operatorname{Pr}($ punishment $)$ & $\%$ change in $p r$ & $\operatorname{Pr}($ punishment $)$ & $\%$ change in $p r$ \\
\hline Median values & 0.026 & NA & 0.063 & NA \\
\hline Polity $=7$ & $0.054^{*}$ & $+108 \% *$ & $0.086^{*}$ & $+37 \% *$ \\
\hline Polity $=-9$ & $0.023^{*}$ & $-12 \% *$ & $0.031 *$ & $-51 \% *$ \\
\hline Alliance $=1$ & $0.008^{*}$ & $-69 \% *$ & $0.068^{*}$ & $+8 \% *$ \\
\hline Left-wing & $0.057 *$ & $+119 \% *$ & $0.060^{*}$ & $-5 \% *$ \\
\hline Right-wing & $0.005^{*}$ & $-80 \% *$ & $0.034 *$ & $-46 \% *$ \\
\hline GDP per capita $=\$ 1,000$ & 0.024 & $-8 \%$ & $0.074 *$ & $+18 \% *$ \\
\hline$G D P$ per capita $=\$ 12,000$ & 0.034 & $+31 \%$ & $0.039^{*}$ & $-38 \% *$ \\
\hline
\end{tabular}

Note: * indicates statistical significance.

none of the pooled results we described were driven by peculiarities of the Cold War period. ${ }^{61}$ Comparing the estimates for the Cold War and post-Cold War periods, standard errors are larger in the smaller, Cold War sample, leading to fewer significant coefficients. Most of the signs of coefficients are unchanged; a few coefficients change sign as we move back to the Cold War period, but none of these is significant. These results provide reassurance about our interpretation of the pooled results.

On the other hand, the US vote-buying strategy changed in several significant ways after the Cold War. To illustrate these effects, Table 3 presents the marginal effects of key regressors on US punishment strategies during and after the Cold War. First, US treatment of allies changed sharply. The United States was slightly more likely to punish allies than non-allies in the pooled sample, although this coefficient was not significant. During the Cold War, however, the United States was significantly less willing to punish its allies, which reflected the constraints imposed by a tense global rivalry with the Soviet Union. Alliance with the United States during the Cold War reduced the probability of punishment after voting against the United States by more than two-thirds. After the end of the Cold War, by contrast, the United States became significantly more willing to punish allies than non-allies, as systemic constraints relaxed. In the post-Cold War era, allies were 8 percent more likely to be punished than non-allies if they voted in opposition, which is a stark change from the Cold War period. The pooled results concealed a sharp change in US policy.

During the Cold War the United States felt compelled to woo its allies; after the Cold War, it expected its allies to tow the line or face the consequences. During the Cold War, the United States was much more willing to punish left-leaning

61. We also estimate a model in which a Cold War variable is interacted with each regressor, and find similar results. We focus on the split-sample approach here as the full interactions model makes interpretation of a somewhat complicated model even more complicated. See Ai and Norton 2003; or Braumoeller 2004, for details. 
governments than either right-leaning or centrist governments. Left-leaning governments were 119 percent more likely to be punished if they voted against a US position than the baseline centrist category, and they were more than ten times more likely to be punished than right-leaning governments. During the post-Cold War era, in contrast, leftist governments were not treated much differently than centrist governments, and the difference in the treatment of right-leaning versus left-leaning governments diminished significantly. The reduced salience of left-leaning political orientation after the end of the Cold War reflected the collapse of the left as a global challenge to the capitalist economic model. Finally, there was a marked shift after the end of the Cold War in the effect of the recipient's level of development. During the Cold War, the effect of per capita GDP on the US punishment strategy was only marginally significant, but it appeared to be the case that higher-income countries were punished more frequently than poorer ones. On the other hand, after the Cold War poor countries were more than seven times more likely to be punished than middle-income countries if they voted against US positions. It was logical to target poor countries, because they were more dependent on foreign aid than countries with more highly developed economies, and the behavior of poor countries indicates that they were more vulnerable to influence attempts. The fact that US strategy did not target poor countries in this way until the end of the Cold War suggests that the Cold War competition for the allegiance of the developing world undermined the credibility of US influence attempts.

Our central result about the role of democracy does not change with the end of the Cold War. In both the Cold War and the post-Cold War subsamples, as in the pooled model, the United States is much more likely to punish and reward democracies than autocracies. This suggests that, although many other features of US foreign policy shifted dramatically with the end of the Cold War, the relationship between US foreign aid and authoritarian regimes did not. Certain authoritarian regimes lost US support because the Cold War ended, but the same logic applies during the Cold War and after: autocratic regimes that receive US foreign aid do so because they play key roles in US foreign policy. Consequently, they cannot be punished when they defy US preferences. The US public is sympathetic toward democracies, so democracies receive foreign aid that is not critical to foreign policy and can be used strategically to buy votes. Furthermore, it is politically acceptable to give democracies additional aid when that becomes expedient, so it is credible to offer to increase aid as an inducement. Consequently, it is more credible for the United States to punish and reward democracies.

\section{A Direct Test of Strategic Voting}

The results of this study provide substantial evidence that recipient countries, especially democracies, vote strategically in anticipation of aid-based punishments and rewards. However, it is possible to directly test the proposition that the relationship between the substantive regressors and democratic voting behavior is affected by strategic interaction in the way that we propose. Does recipient voting behavior really 
depend on subsequent US aid disbursement decisions? The obvious way to assess this is to use comparative model testing methods to compare the strategic model with a nonstrategic model of recipient voting behavior that uses the same regressors. ${ }^{62}$ Such a test has two key implications. From a methodological perspective, a comparative model test will assess whether the additional machinery that the strategic model requires improves model fit enough to be justified, given our data. From a substantive perspective, it represents a direct test of the hypothesis that recipient voting behavior depends on expected punishments and rewards. ${ }^{63}$

In our case, we can rely on a simple likelihood-ratio test, which is appropriate for nested models. The model presented in Table 1 assumes that the recipient conditions its vote choice on its anticipated effect on the US aid disbursement decision. Furthermore, we show that democracies are the regimes affected by strategic voting calculations, as US punishments and rewards are more credible when applied to them. However, if it is the case that the recipient's voting decision is not strategic (or, equivalently, is unaffected by aid disbursement decisions), we do not need to condition its choice on the expected response of the United States. In this alternative model of recipient voting behavior we include the same substantive regressors included in the recipient's utilities without conditioning their influence on US behavior. Thus, the restricted model is a logit model with each of the regressors in Table 1 included once. This simpler model is nested within the strategic estimator because the full model can be reduced to the restricted model with a set of linear restrictions. ${ }^{64}$ The likelihood ratio test comparing the two models of democratic voting behavior rejects the null hypothesis that the restricted model performs equally well at a high level of confidence $(p<$ 0.005). ${ }^{65}$ Thus, we conclude that the nonstrategic model is indeed misspecified for democracies, as we assumed at the outset, and that a properly specified model must include strategic interaction. Substantively, this means that US aid policy has a significant effect on the voting behavior of democratic members of the UNGA.

The comparative model test also allows us to assess where in the data our strategic model gives us greater leverage. To assess this, we classify observations according to whether the strategic or the nonstrategic model makes a more accurate prediction of the observed outcome. A key implication of our explanation for strategic voting by democracies is that a strategic model should particularly improve the fit for

62. See Clarke 2001 and 2003.

63. Alternative strategic models could be formulated that might fit the data better. However, from our perspective the substantively interesting question is whether threatened punishments and rewards are effective at influencing UNGA voting. Therefore, the relevant null hypothesis is a model using the same covariates that assumes that this is not the case.

64. Clarke 2001, 727-28.

65 . The log-likelihood for the strategic version of the recipient vote choice model is -1458.88 , whereas the log-likelihood for the restricted nonstrategic model is -1493.70 . Because the strategic model has eight additional parameters, the likelihood ratio test statistic is 69.64 with eight degrees of freedom. This indicates that the strategic model outperforms the nonstrategic version, as the Chi-square distributed test statistic of 69.64 is significant at any conventional level of statistical significance. The critical value for significance at the 0.005 level is 21.96 . 
democratic countries, because democratic countries' votes are affected more by anticipated punishments and rewards than are the votes of autocratic countries. We find that this is indeed the case. ${ }^{66}$ The strategic model improved the fit for 72 percent of predictions for democratic observations. In contrast, the nonstrategic model performs similarly to the strategic model for autocratic countries with Polity score of less than 6. Similar patterns hold for other variables that significantly affect the recipient utilities. For instance, the model provides better predictions for allies in 71 percent of the observations, and non-allies in only 40 percent of observations. However, if we focus only on democracies, the strategic model provides better predictions for 79 percent of the observations for allies, and 65 percent for non-allies.

We used the case of Pakistan to illustrate our argument earlier, arguing that Pakistan was a case in which punishments and rewards occurred much more frequently during democratic regime years than during autocratic years, so it seems appropriate to return to that example here. ${ }^{67} \mathrm{We}$ find an improvement in our predictions in only 22 percent of nondemocratic observations using our strategic model, but we find an improvement in 81 percent of observations in which Pakistan had a democratic regime. Since the only difference between the models relates to predicted voting behavior, this indicates that Pakistan's UN voting record was in fact more consistently influenced by the US votebuying strategy during the democratic years.

\section{Conclusion}

A simple strategic model reveals layers of interaction that lie beneath the radar of conventional analysis. The empirical analysis leads to several important substantive findings. Our central finding involves the relationship between democracy and support for US foreign policy. We started with the observation that democratic countries vote with the United States more often than autocratic countries on important votes. Is this because democracies have inherently aligned preferences, or because the United States punishes and rewards democracies more frequently than autocracies? These alternative interpretations have quite different normative implications, and it is impossible to distinguish among them without a model that allows recipient governments to strategically alter their votes in anticipation of punishments or rewards.

Modeling the strategic relationship between voting and aid flows makes it possible to estimate quantities of interest that are not directly observable, allowing us to sort out causal explanations that would otherwise be observationally equivalent. Our results are inconsistent with the first hypothesis: democracies in the developing world are in fact more critical of US positions in the United Nations than autocracies, probably because they are sensitive to public opinion. Nevertheless, democracies comply more with US voting preferences than autocracies do, because the United 
States is more likely to carry out threats and promises to manipulate aid if the target country is a democracy. This is attributable to the credibility problems that frustrate US efforts to link aid to autocratic countries with UN voting. Democracies are sensitive to this strategy, particularly to threats of sharp aid reductions. We show that democracies are more compliant than nondemocratic regimes only under circumstances that render credible the US threat to suspend aid.

These findings have profound normative implications, and they can only be disheartening for students of US foreign policy or of multilateral institutions. In a parliament of parliaments and dictators, it is disturbing that the United States disproportionately uses changes in aid disbursements to manipulate the voting behavior of poor democracies. Further, to the degree that the legitimacy of UN decisions depends on the democratic legitimacy of its members, it is unfortunate that US foreign policy systematically coerces the votes of democracies.

On the other hand, while our results indicate that US policy influences countries' votes, they also point to the limits of that influence. Although the important resolutions that the United States supports generally pass, these represent a minority of important votes, and resolutions that the United States opposes almost always pass as well. In addition to democracy, our results suggest that economic development is a fault line in the UNGA. The poorest members of the UNGA, although they are most vulnerable to sanctions, are nevertheless the most resistant to US pressure to conform. Poor countries appear to resist because they have strongly held preferences that clash with US objectives. Similarly, countries that trade intensively with the United States are highly vulnerable to US influence attempts, but are nevertheless more resistant to US influence. In this case, however, resistance is not attributable to deep-seated conflict of interest, because countries that trade with the United States tend to share US preferences. Instead, countries that trade intensively vote against the United States more frequently because it is too costly for the United States to link their votes in the UN to punishments or rewards. The fact that many countries defy US pressure indicates that the votes are regarded as sufficiently important to justify bearing some costs, and they therefore retain substantial informational content.

Nevertheless, an important methodological implication of our findings is to draw into question the use of UNGA voting as a straightforward index of states' preferences. ${ }^{68} \mathrm{UN}$ voting records are a uniquely informative data source on the policy preferences of most of the world's countries on a wide range of issues, and previous scholarship has frequently treated UN voting either as a measure of preferences or as an arena for vote buying. Our innovation is to use a strategic statistical model that explicitly allows for the possibility that voting is strategic, and we find that the US policy of influencing important UNGA votes with aid disbursements has important effects on the voting behavior of democratic recipients. A model specification test rejects the hypothesis that democratic voting decisions are unaffected by subsequent aid disbursement strategies. This result rejects the hypothesis that UN voting on 
issues of political significance to major aid donors is simply a sincere expression of country preferences.

\section{Supplementary material}

Supplementary Material for this article is available at http://dx.doi.org/10.1017/ S0020818314000186.

\section{References}

Ai, Chunrong, and Edward C. Norton. 2003. Interaction Terms in Logit and Probit Models. Economics Letters 80 (1):123-29.

Alesina, Alberto, and David Dollar. 2000. Who Gives Aid to Whom and Why? Journal of Economic Growth 5 (1):33-63.

Alesina, Alberto, and Beatrice Weder. 2002. Do Corrupt Governments Receive Less Foreign Aid? American Economic Review 92 (4):1126-37.

Alvarez, Michael E., José Antonio Cheibub, Fernando Limongi, and Adam Przeworski. 2000. Democracy and Development: Political Institutions and Well-being in the World, 1950-1990. New York: Cambridge University Press.

Andersen, Thomas Barnebeck, Thomas Harr, and Finn Tarp. 2006. On US Politics and IMF Lending. European Economic Review 50 (7):1843-62.

Apodaca, Clair, and Michael Stohl. 1999. United States Human Rights Policy and Foreign Assistance. International Studies Quarterly 43 (1):185-98.

Barro, Robert J., and Jong-Wha Lee. 2005. IMF Programs: Who Is Chosen and What Are the Effects? Journal of Monetary Economics 52 (7):1245-69.

Bas, Muhammet Ali, Curtis S. Signorino, and Robert W. Walker. 2008. Statistical Backwards Induction: A Simple Method for Estimating Recursive Strategic Models. Political Analysis 16 (1):21-40.

Bennett, D. Scott, and Allan C. Stam. 2000. Research Design and Estimator Choices in the Analysis of Interstate Dyads: When Decisions Matter. Journal of Conflict Resolution 44 (5):653-85.

Boone, Peter. 1996. Politics and the Effectiveness of Foreign Aid. European Economic Review 40 (2): 289-329.

Boutton, Andrew T., and David B. Carter. 2014. Fair Weather Allies? Terrorism and the Allocation of US Foreign Aid. Journal of Conflict Resolution 58 (7):1144-73. doi: 10.1177/0022002713492649.

Braumoeller, Bear. 2004. Hypothesis Testing and Multiplicative Interaction Terms. International Organization 58 (4):807-20.

Bueno de Mesquita, Bruce, and Alastair Smith. 2007. Foreign Aid and Policy Concessions. Journal of Conflict Resolution 51 (2):251-84.

2009. A Political Economy of Aid. International Organization 63 (2):309-40.

2010. Leader Survival, Revolutions, and the Nature of Government Finance. American Journal of Political Science 54 (4):936-50.

Bueno de Mesquita, Bruce, Alastair Smith, Randolph M. Siverson, and James D. Morrow. 2003. The Logic of Political Survival. Cambridge, MA: MIT Press.

Carrubba, Clifford J., Amy Yuen, and Christopher Zorn. 2007. In Defense of Comparative Statics: Specifying Empirical Tests of Models of Strategic Interaction. Political Analysis 15 (4):465-48.

Carter, David B. Forthcoming. The Compellence Dilemma: International Disputes with Violent Groups. International Studies Quarterly. 
Cashel-Cordo, Peter, and Steven Craig. 1997. Donor Preferences and Recipient Fiscal Behavior: A Simultaneous Analysis of Foreign Aid. Economic Inquiry 35 (3):653-71.

Cheibub, José Antonio, Jennifer Gandhi, and James Raymond Vreeland. 2010. Democracy and Dictatorship Revisited. Public Choice 143 (1-2):67-101.

Chiozza, Giacomo. 2007. Disaggregating Anti-Americanism: An Analysis of Individual Attitudes Toward the United States. In Anti-Americanisms in World Politics, edited by Peter J. Katzenstein, and Robert O. Keohane, 93-126. Ithaca, NY: Cornell University Press.

- 2009. Anti-Americanism and the American World Order. Baltimore, MD: Johns Hopkins University Press.

Clarke, Kevin. 2001. Testing Nonnested Models of International Relations: Reevaluating Realism. American Journal of Political Science 45 (3):724-44.

. 2003. Nonparametric Model Discrimination in International Relations. Journal of Conflict Resolution 47 (1):72-93.

Collier, Paul, and David Dollar. 2002. Aid Allocation and Poverty Reduction. European Economic Review 46 (8):1475-500.

Demirel-Pegg, Tijen, and James Moskowitz. 2009. US Aid Allocation: The Nexus of Human Rights, Democracy, and Development. Journal of Peace Research 46 (2):181-98.

Dixon, William J. 1994. Democracy and the Peaceful Settlement of International Conflict. American Political Science Review 88 (1):14-32.

Dreher, Axel, Jan-Egbert Sturm, and James Raymond Vreeland. 2009. Development Aid and International Politics: Does Membership on the UN Security Council Influence World Bank Decisions? Journal of Development Economics 88 (1):1-18.

Dreher, Axel, Peter Nunnenkamp, and Rainer Thiele. 2008. Does US Aid Buy UN General Assembly Votes? A Disaggregated Analysis. Public Choice 136 (1-2):139-64.

Gartzke, Erik. 2006. The Affinity of Nations, 1946-2002 Codebook. Version 4.0. Columbia University. Available at <http://pages.ucsd.edu/ egartzke/data/affinity_codebook_03102006.pdf>. Accessed 15 February 2014.

- 2007. The Capitalist Peace. American Journal of Political Science 51 (1):166-91.

Girod, Desha M. 2012. Effective Foreign Aid Following Civil War: The Nonstrategic-Desperation Hypothesis. American Journal of Political Science 56 (1):188-201.

Huth, Paul K., and Todd L. Allee. 2002. Domestic Political Accountability and the Escalation and Settlement of International Disputes. Journal of Conflict Resolution 46 (6):754-90.

Keefer, Philip. 2007. Database of Political Institutions. Washington, DC: Development Research Group, World Bank.

Kegley, Charles W., and Steven W. Hook. 1991. US Foreign Aid and UN Voting: Did Reagan's Linkage Strategy Buy Deference or Defiance? International Studies Quarterly 35 (3):295-312.

Keohane, Robert, Stephen Macedo, and Andrew Moravscik. 2009. Democracy-Enhancing Multilateralism. International Organization 63 (1):1-31.

Kilby, Christopher. 2013. An Empirical Assessment of Informal Influence in the World Bank. Economic Development and Cultural Change 61 (2):431-64.

Kuziemko, Ilyana, and Eric Werker. 2006. How Much Is a Seat on the Security Council Worth? Foreign Aid and Bribery at the United Nations. Journal of Political Economy 114 (5):905-30.

Lai, Brian, and Dan Reiter. 2000. Democracy, Political Similarity, and International Alliances, 1816-1992. Journal of Conflict Resolution 44 (2):203-27.

Lake, David A. 2002. Rational Extremism: Understanding Terrorism in the Twenty-first Century. Dialog IO 1 (1):15-29.

Maizels, Alfred, and Machiko K. Nissanke. 1984. Motivations for Aid to Developing Countries. World Development 12 (9):879-900.

Mansfield, Edward D., Helen V. Milner, and B. Peter Rosendorff. 2000. Free to Trade: Democracies, Autocracies, and International Trade. American Political Science Review 94 (2):305-21.

Milner, Helen, and Dustin Tingley. 2010. The Political Economy of US Foreign Aid: American Legislators and the Domestic Politics of Aid. Economics and Politics 22 (2):200-32. 
2013. The Choice for Multilateralism: Foreign Aid and American Foreign Policy. Review of International Organizations 8 (3):313-41.

Mitchell, Sara McLaughlin, and Paul R. Hensel. 2007. International Institutions and Compliance with Agreements. American Journal of Political Science 51 (4):721-37.

Neumayer, Eric. 2003. Do Human Rights Matter in Bilateral Aid Allocation: A Quantitative Analysis of Twenty-one Donor Countries. Social Science Quarterly 84 (3):650-66.

Oatley, Thomas, and Jason Yackee. 2004. American Interests and IMF Lending. International Politics 41 (3):415-29.

Oneal, John, and Bruce Russett. 2005. Rule of Three, Let It Be? When More Really Is Better. Conflict Management and Peace Science 22 (4):293-310.

Pevehouse, Jon C. 2002. Democracy from the Outside-In? International Organizations and Democratization. International Organization 56 (3):515-49.

Pevehouse, Jon C., and Edward Mansfield. 2006. Democratization and International Organizations. International Organization 60 (1):137-67.

Poe, Steven C., and James Meernik. 1995. US Military Aid in the 1980s: A Global Analysis. Journal of Peace Research 32 (4):399-411.

Rai, Kul B. 1980. Foreign Aid and Voting in the UN General Assembly. Journal of Peace Research 17 (3): 269-77.

Russett, Bruce. 1993. Grasping the Democratic Peace: Principles for a Post-Cold War World. Princeton, NJ: Princeton University Press.

Russett, Bruce, and John Oneal. 2001. Triangulating Peace: Democracy, Interdependence, and International Organizations. New York: Norton.

Schraeder, Peter J., Steven W. Hook, and Bruce Taylor. 1998. Clarifying the Foreign Aid Puzzle. World Politics 50 (2):294-323.

Serafino, Nina M. 1990. Nicaraguan Elections and Transition: Issues for US Policy. CRS Report 90-187F. Washington, DC: Library of Congress, Congressional Research Service. 26 March.

Signorino, Curtis S. 1999. Strategic Interaction and the Statistical Analysis of International Conflict. American Political Science Review 93 (2):279-97.

- 2003. Structure and Uncertainty in Discrete Choice Models. Political Analysis 11 (4):316-44.

Signorino, Curtis S., and Kuzey Yilmaz. 2003. Strategic Misspecification in Regression Models. American Journal of Political Science 47 (3):551-66.

Steinwand, Martin C., and Randall W. Stone. 2008. The International Monetary Fund: A Review of the Recent Evidence. Review of International Organizations 3 (2):123-49.

Stone, Randall W. 2004. The Political Economy of IMF Lending in Africa. American Political Science Review 98 (4):577-91.

— 2008. The Scope of IMF Conditionality. International Organization 62 (4):589-620.

2011. Controlling Institutions: International Organizations and the Global Economy. Cambridge, UK: Cambridge University Press.

Svensson, Jakob. 1999. Aid, Growth and Democracy. Economics and Politics 11 (3):275-97.

Thacker, Strom C. 1999. The High Politics of IMF Lending. World Politics 52 (1):38-75.

Voeten, Erik. 2005. United Nations General Assembly Voting Data. Version 2.0 Available at <http://thedata.harvard.edu/dvn/dv/Voeten/faces/study/StudyPage. $x$ html?studyId=38311\&studyListingIndex $=0$ dee53f12c760141b21c251525332>. Accessed 11 March 2014.

Vreeland, James Raymond. 2008. The Effect of Political Regime on Civil War: Unpacking Anocracy. Journal of Conflict Resolution 52 (3):401-25.

Wang, T.Y. 1999. US Foreign Aid and UN Voting: An Analysis of Important Issues. International Studies Quarterly 43 (1):199-210.

Wittkopf, Eugene. 1973. Foreign Aid and United Nations Votes: A Comparative Study. American Political Science Review 67 (3):868-88.

Wright, Joseph, and Matthew Winters. 2010. The Politics of Effective Foreign Aid. Annual Review of Political Science 13:61-80. 